ARTICLE

\title{
Strategic Aspects of Professional Position Development: Implications for Adjustment from Administrative to Professional Positions in Indonesia
}

\author{
Rati Sumanti ${ }^{\star}$, Ervina Yunita, and Henri Prianto Sinurat \\ Puslatbang KHAN, Jl. Dr. Mr. Muhammad Hasan, Lamcot, Aceh Besar, Indonesia
}

How to cite: Sumanti, Rati., Yunita, Ervina and Sinurat, Henri Prianto. (2021). Strategic Aspects of Professional Position Development: Implications for Adjustment from Administrative to Professional Positions in Indonesia. Jurnal Borneo Administrator, $17 \quad$ (3), 351-364. https://doi.org/10.24258/jba.v17i3.898

\section{Article History \\ Received: 17 May 2021 \\ Accepted: 22 December 2021}

\section{Keywords:}

Flattening Bureaucracy, Professional Position, Development of Position

\begin{abstract}
The mandate of government policy is to flatten bureaucracy structure through transferring administrative positions to professional ones. Such policy has caused many issues. Thus, it is necessary to develop professional positions. This research analyses three strategic aspects of professional position development that include legal, technical, and welfare aspects using a systematic literature review method. It shows that the legal aspect requires certain policies to accelerate the implementation of flat bureaucracy and problem-solving in organizational structure as well as in personnel management. The government's commitment is required by the planning system related to the development of professional positions both at the central and regional levels. In the technical aspect, the analysis shows competency development become mandatory for agencies to solve the competency gap between administrative positions and professional positions. Then on the welfare aspect, there is an income gap between administrative positions and several professional positions. The government has to make a regulation about allowance to resolve the income gap.
\end{abstract}

\section{A. INTRODUCTION}

Government human resource development is very important for a successful organization thus it is necessary to manage strategically (Burma, 2014). Consequently, the government must be able to manage its human resources. As expressed by Rohida, Nuryanto, \& Syarif (2018) that good personnel management based on qualifications, competence, morality, and integrity as well as institutional needs can realize government human resources to become part of the solutions and not part of the problems. To make this happen, it is necessary to pay attention to seven trends of future bureaucratic changes that will transform the way bureaucracy works. One of them is dynamic and flexible personnel management (Faedlulloh, Maarif, Meutia, \& Yulianti (2020:326). Theoretically and empirically, simplification of the bureaucratic structure is deemed necessary because the characteristics that are too bureaucratic are no longer in line with bureaucratic reform which results in obstruction of the professional development of its human resources (Nurhestitunggal \& Muhlisin, 2020:14). The simplification of the bureaucratic structure was carried out by

\footnotetext{
* Corresponding Author

Email : ratisumanti@gmail.com
} 
trimming structural or managerial positions in echelons III and IV to professional positions that had close tasks and functions.

Based on data from The National Civil Service Agency (hereinafter referred to as BKN) on December 2020, the number of civil servants in Indonesia is $4,168,118$. Consisting of 456,372 structural positions (Director General and Director Level (JPT) and Administrator or Manager Level (JA)), 2,080,942 professional positions and 1,630,804 administrative positions. More details on the distribution of civil service positions can be seen in Table 1 below.

Table 1. Distribution of Civil Servants in Indonesia

\begin{tabular}{|c|c|c|c|c|}
\hline $\begin{array}{l}\text { JPT (Director General and } \\
\text { Director Level position) }\end{array}$ & \multicolumn{2}{|c|}{$\begin{array}{c}\text { JA (Administrator/ } \\
\text { Manager Level position) }\end{array}$} & \multicolumn{2}{|c|}{$\begin{array}{l}\text { JF (Professional } \\
\text { Position) }\end{array}$} \\
\hline Prime $\quad 0,004 \%$ & $\begin{array}{l}\text { Office } \\
\text { Administrator }\end{array}$ & $22 \%$ & Teacher & $68 \%$ \\
\hline Intermediate & Supervisory & $70 \%$ & Lecturer & $4 \%$ \\
\hline Junior & $\begin{array}{l}\text { Administrative } \\
\text { staff }\end{array}$ & $3 \%$ & Medical & $16 \%$ \\
\hline & & & Technical & $12 \%$ \\
\hline
\end{tabular}

Source : National Civil Service Agency (BKN, 2020)

From the table above, it is known that the distribution of civil servant positions is dominated by supervisory positions, that is 70 percent of the total number of structural positions, followed by administrator positions 22 percent. The existence of JPT and JA also slows down the flow of bureaucracy in Indonesia. Organizational simplification is carried out to obtain a profile of government institutions that have the right function, right process, and right size (Arsalam, 2020:158). Bureaucratic simplification also aims to create a more dynamic and professional bureaucracy as an effort to increase effectiveness and efficiency to support the performance of public services (Ministry of Administrative and Bureaucratic Reform Regulation (hereinafter referred to as Permen PAN RB) Number 28 of 2019). In addition, the results of examination of the effectiveness of simplifying the government bureaucracy, there is a significant influence between organizational structure on Civil Servants (hereinafter referred to as ASN) performance. The results of the analysis show that the more effective the bureaucratic echelon simplification policy, the more wasteful it will be to eliminate waste and improve performance (Nizamuddin, 2020:157).

This illustrates that the policy of simplifying the bureaucracy by cutting administrator/manager positions (echelon III and IV) is very appropriate to implement. The reduction of administrative/managerial positions will cut the bureaucratic pathway which has been very hierarchical to become agile (agile bureaucracy) so that it has the opportunity to accelerate decision making and government administration processes (Purwanto, 2020:175). Previous research from Andhika (2018:21), states that simplification of the bureaucratic structure will bring good service quality because it shortens procedures and minimizes the level of the service hierarchy. The table above also shows the comparison of several JF numbers which are dominated by teachers as much as 68 percent of the total existing professional positions. In terms of the urgency of this comparison, it has not been reflected in its current distribution, even though there are 243 types of JF are collected in $25 \mathrm{JF}$ categories.

The data above indicates that there is a need to simplify the bureaucracy by transferring administrative positions to professional ones. However, this policy certainly also has implications that need to be researched and analyzed so that it does not become biased when implemented. This is the concern of Situmorang (2019:1251) who hopes that the implementation of bureaucratic simplification policies must be able to provide assurance that normative rights, benefits, position paths, and employee ranks are not 
hampered. Furthermore, Daniarsyah (2020:10) suggests the results of his research related to the implications of the bureaucratic simplification policy through the transformation of administrative positions into professional positions which have the potential to lead to very high counterproductive work behaviours. Purwanto (2020:184) also concludes that the implication of transferring administrative positions to professional positions makes the fate of employees uncertain. In his analysis, the policy implications are adjusted for the age of the employees. Furthermore, Purwanto mention that officers who are approaching retirement age feel resistant to the policy, while officials who are young and productive prefer administrator positions rather than professional positions because they get lots of fringe benefits and welfare. Different researchers assign different timeframes to each employees generation. Twenge in Thompson (2017:27) classifications include the following: the veterans (born 1925-1945), the baby boomers, (born 1946-1964), Generation X or Gen X (born 1965-1981), and Generation Y or Gen Y also referred to as GenMe, millennials, and nGen, (born 19821999). If the work tenure of civil servants is until 58 years old, then in 2021 civil servants who were born in 1964 (the baby boomers) and in 1965 (Gen X) will enter retirement age. Gen $\mathrm{Y}$ is focused on individual career development, while Gen $\mathrm{X}$ will be oriented towards career development, directed the development of the organization (Nindyati, 2017:59). If the organization is not able to provide fair support to administrator/managers who will switch to professional positions and are unable to sit in places that are in line with their abilities, then the potential for counterproductive work behaviours will occur (Daniarsyah, 2020:727).

The simplification of the bureaucratic structure through the transfer of administrator/managerial positions to professional one is a new policy, so there is not many research related to this matter. Situmorang (2019), Daniarsyah (2020), Purwanto (2020) discuss the implications of this policy is not comprehensive enough and difficult to map out a strategy to resolve it. This scientific article comprehensively presents strategic aspects of professional position development originating from the transfer of administrative positions. This study refers to several references related to the urgency of simplifying the bureaucracy and the implications of the policy of transferring administrative positions to professional ones. From some of these literature sources, the author concludes that there are three strategic aspects of professional position development including legal/law aspects, operational technicalities, and welfare. These aspects are in accordance with the need for the development of professional positions as a result of the policy of transferring administrative/managerial positions to professional position. Therefore, the authors hope that the results of this analysis will contribute to knowledge and can be used as a reference to policy-making in the field of civil servant management in terms of career development of professional positions from the results of equalizing administrative positions, especially when changing positions in the context of strengthening bureaucratic reform.

\section{B. LITERATURE REVIEW}

Bureaucratic simplification is a general term used to refer to a form of bureaucratic restructuring. Bernardian and Russel in Anita et al. (2020), suggest eight ways to restructure bureaucracy, namely downsizing, delayering, decentralizing, reorganization, cost reduction strategy, IT innovation, competency measurement and performance-related pay. In some references, it is also known as flattening (Dahlia, 2020; Kubheka et al., 2013).

In Indonesia, simplification of the bureaucracy through the equalization of administrative positions to professional positions aims to create a more dynamic and professional bureaucracy in an effort to increase the effectiveness and efficiency of government service performance (PermenPAN-RB Number 28 of 2019 concerning The Transfer of Managerial Positions Into Functional ones, 2019). Zulyani \& Meiwanda (2020:89) criticize that the current bureaucracy becomes a world-class bureaucracy determined by the quality of 
professional and world-class government human resources. This problem is also a concern of Dahlia (2020:1), in her paper analyzing the urgency of simplifying the bureaucracy due to the low level of competitiveness and human resources.

Faedlulloh, Yulianto, \& Karmilasari (2020:75) concluded there are still many barriers that must be faced to achieve a bureaucracy that is not bureaucratic. Sedarmayanti in Toimsar, Basri, \& Manguntara (2018:56) characterizes the simplification of management, namely organizations that are filled with many professional positions. Professional positions can strengthen organizational performance because the skills and expertise have a strategic role to achieve performance (Rohida et al., 2018:21). Sudrajat (2013:84) has written an idea of professionalization in the framework of bureaucratic reform. In his article, it is stated that the idea is a form of criticism and evaluation of the bureaucracy which is then manifested through unilaterally making rules and systems. In addition, it is also due to the demands of the community for the bureaucracy which implements many poor practices.

The results of the study by Anita et al. (2020:94) analysed the impact of the policy of equalizing administrative positions to professional positions using fishbone analysis.

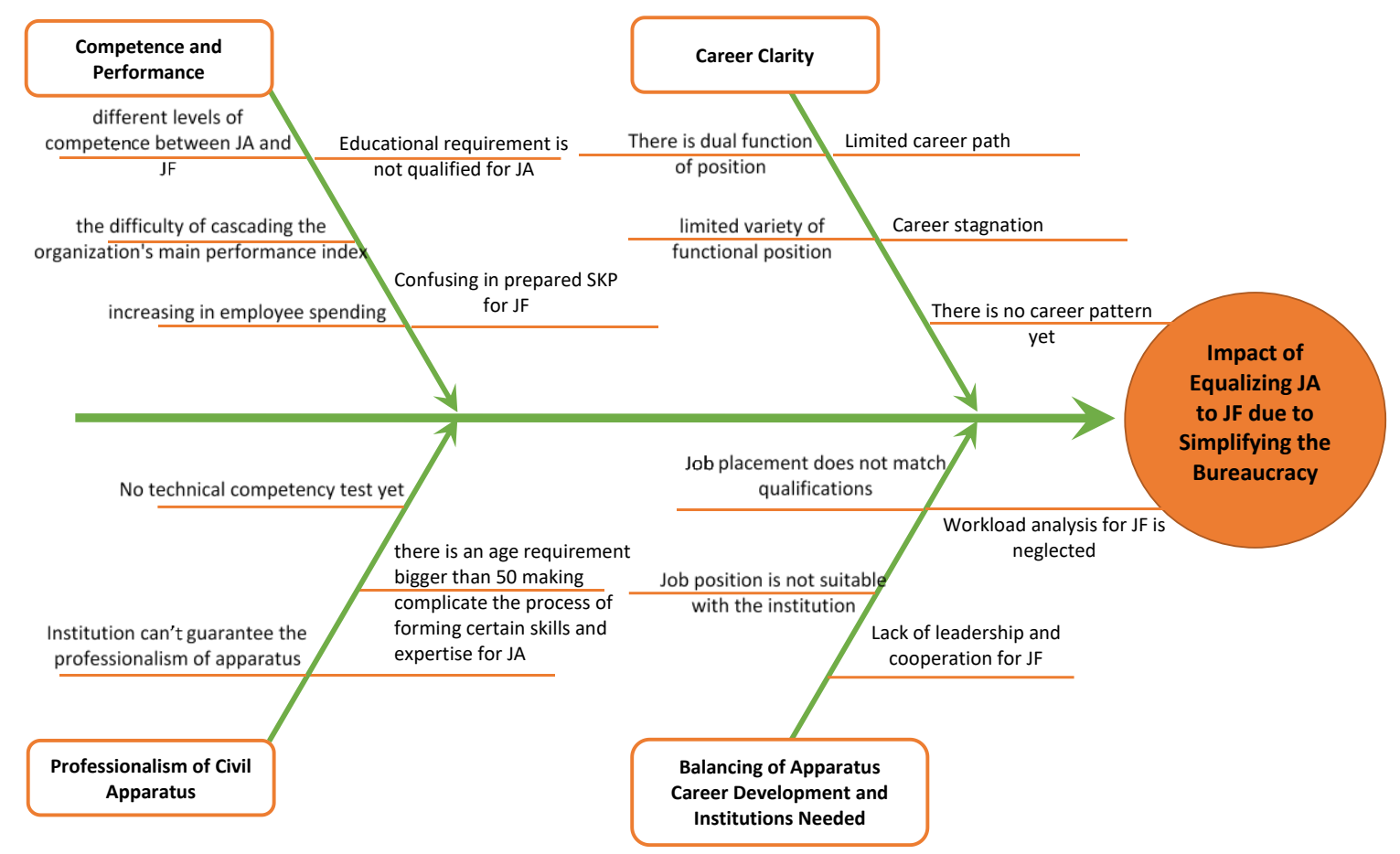

Source : Anita et al. (2020:94)

Picture. 1 Fishbone Analyzing Impact of Equalizing JA to JF in the Context of Simplifying the Bureaucracy

The results of research conducted by (Fitrianingrum, Lusyana, \& Lellyana, 2020:53) analyzed that the challenges and implementation of career development for professional positions from the results of equalizing administrative positions were seen from four factors, namely communication, resources, disposition, or attitude, and bureaucratic structure. From the communication factor, it was found that the lack of clear socialization consistently led to confusion for administrative officials regarding career development after being equalized. In terms of resources and disposition, it is not too challenging. Meanwhile, the bureaucratic structure factor is not in line with the policy so that optimization through organizational design and post-equalization organizational structure with new business processes with new competency-based social interactions.

From the analysis above, it is clear that the development of a professional position as an implication of transferring an administrative position to a professional one needs to be 
mapped immediately so that the adverse effects can be minimized (Daniarsyah, 2020:729). Daniarsyah also explained that development can be done by carrying out organizational development, position and training development.

\section{METHOD}

The research method used a desk study, by collecting data and information based on examination and analysis of data and information using secondary data. The author uses this method because it only uses literature reviews without directly collecting data. As for several sources of literature that are used as references to determine the urgency of simplifying the bureaucracy and the implications of the policy of transferring administrative positions to professional positions, research by Nurhestitunggal \& Muhlisin, (2020:14) with the article entitled Simplification of the Bureaucratic Structure: A Review of Theoretical and Empirical Perspectives on Echelon III and IV Elimination Policies, and the results of research from Andhika (2018:21) entitled From Traditional Bureaucratic Structure to Model Adhocracy: Innovative Organizational Structure. The author also uses a reference from Situmorang (2019:1251) with the title of the writing is Study of Analysis of the ASN Law, towards Simplifying the Bureaucracy, then also from Daniarsyah (2020:10) with the title of the article, Dispelling Counterproductive Behavior: Transforming an Administrative Position into a Professional Position, and last is the writing of Purwanto (2020:184) with the title Implication of Bureaucratic Reform Policy In Echelon III and IV In The Environmental Services Office of Blora Regency.

This equalization aims to create a more dynamic and professional bureaucracy as an effort to increase effectiveness and efficiency performance of government services to the public. The results of the study show that communication factors and bureaucratic structures that influence the implementation of this policy are still not optimal and changes in mindset are also other important factors (Fitrianingrum et al, 2020:43).

The research findings of Aulia Rakhman (2020:53) showed that the income received by Echelon III (administrator) was bigger than those with the same job class as expert level professional, meanwhile the income received by echelon IV (supervisor) will increase if they are reposition from structural to professional position.

Authors refers to several references contained in the table below for analysis development of competencies for professional positions.

Table 2. Analysis of Strategic Aspects of Professional Position Development

\begin{tabular}{|c|c|c|c|c|}
\hline No & Research & $\begin{array}{c}\text { Legal/law } \\
\text { Aspect }\end{array}$ & $\begin{array}{c}\text { Operational } \\
\text { Technical } \\
\text { Aspect } \\
\end{array}$ & Welfare Aspect \\
\hline 1 & $\operatorname{Irfan}(2013)$ & - & $\sqrt{ }$ & $\sqrt{ }$ \\
\hline 2 & Makmur (2013) & - & $\sqrt{ }$ & - \\
\hline 3 & Sudrajat (2013) & $\sqrt{ }$ & - & - \\
\hline 4 & Burma (2014) & - & $\sqrt{ }$ & $\sqrt{ }$ \\
\hline 5 & Kuncara (2014) & - & $\sqrt{ }$ & - \\
\hline 6 & Wati (2017) & $\sqrt{ }$ & - & - \\
\hline 7 & Rohida (2018) & - & $\sqrt{ }$ & - \\
\hline 8 & Anita (2020) & $\sqrt{ }$ & $\sqrt{ }$ & $\sqrt{ }$ \\
\hline 9 & Yohanitas (2020) & - & $\sqrt{ }$ & - \\
\hline 10 & Nizamuddin (2020) & - & - & $\sqrt{ }$ \\
\hline 11 & Daniarsyah (2020) & - & $\sqrt{ }$ & - \\
\hline 12 & Purwanto (2020) & - & $\sqrt{ }$ & $\sqrt{ }$ \\
\hline 13 & Fitrianingrum (2020) & - & $\sqrt{ }$ & $\sqrt{ }$ \\
\hline
\end{tabular}

Source: Processed by authors from various references 
Further explanation regarding this aspect is:

Table 3. Strategic Aspects of Development of Professional Positions

\begin{tabular}{|c|c|c|}
\hline No & Aspect & Scope of Analysis \\
\hline 1 & Legal/Law & $\begin{array}{l}\text { This aspect relates to all regulations as basis for implementing } \\
\text { policies about the duties of professional positions. This aspect } \\
\text { also discusses the government's commitment to planning } \\
\text { strategically development of professional positions in the } \\
\text { future. }\end{array}$ \\
\hline 2 & Operational Technical & $\begin{array}{l}\text { The urgency of this aspect develops the competence of } \\
\text { professional positions as compatible with that of professional } \\
\text { positions in an organization based on their competencies. }\end{array}$ \\
\hline 3 & Welfare & $\begin{array}{l}\text { The urgency of the welfare aspect is for employees affected by } \\
\text { the policy of transferring administrative positions to } \\
\text { professional ones, includes salary, allowance, and } \\
\text { remuneration. }\end{array}$ \\
\hline
\end{tabular}

Source: Processed by authors from various references.

\section{RESULT AND DISCUSSION Strategic Aspects of Professional Development 1. Legal/Law Aspect}

The mandatory for implementing bureaucratic simplification was delegated by the President to the Minister of Administrative and Bureaucratic Reform (Hereinafter referred to as Kemenpan RB) as the ministry responsible for administering government affairs in the field of empowering the civil servants and reforming the bureaucracy. This mandate was followed up by Kemenpan RB by issuing Circular Letters No. 384, 390 and 391 of 2019 concerning Strategic and Concrete Steps to Simplify the Bureaucracy. The Circular is addressed to Cabinet Ministers, Governors, Mayors and Regents. Kemenpan RB became a pilot project of bureaucratic simplification in ministries/state agencies. Regarding this, Kemenpan RB has issued Regulation of the Minister of Administrative and Bureaucratic Reform Number 28 of 2019 concerning Equalization of Administrative Positions into Professional Positions. This regulation serves as a guideline for government agencies to propose equalization of positions. It is stated in Article 5 that for the implementation of equalization of positions, government agencies need to carry out the following steps:

a. Identification of administrative positions in the work unit

b. Mapping of positions and administrative officials affected by bureaucratic simplification

c. Mapping of professional positions that can be occupied by officials affected by bureaucratic simplification

d. Alignment of professional position benefits with administrative position benefits by calculating income in administrative positions to professional positions

e. Coordination of professional job class with administrative job class.

It is also stated in Article 13 that government agencies that propose the results of identification of equal positions will be reviewed and validated. The results will become a consideration for the Minister to approve the proposal. If it has been approved, a recommendation letter will be issued which will become the basis for the personnel guidance official to appoint and appoint an equalized professional official. The regulation targets on the equalization of positions must be completed by June 30, 2020. Agencies submitting proposals for equalization of positions are dominated by central agencies. However, until December 31,2020, within the scope of the central agencies, only 74 out of 181 proposed agencies. Meanwhile, in the scope of regional agencies, there are only 19 regional agencies that have just submitted proposals for equalization of positions. 


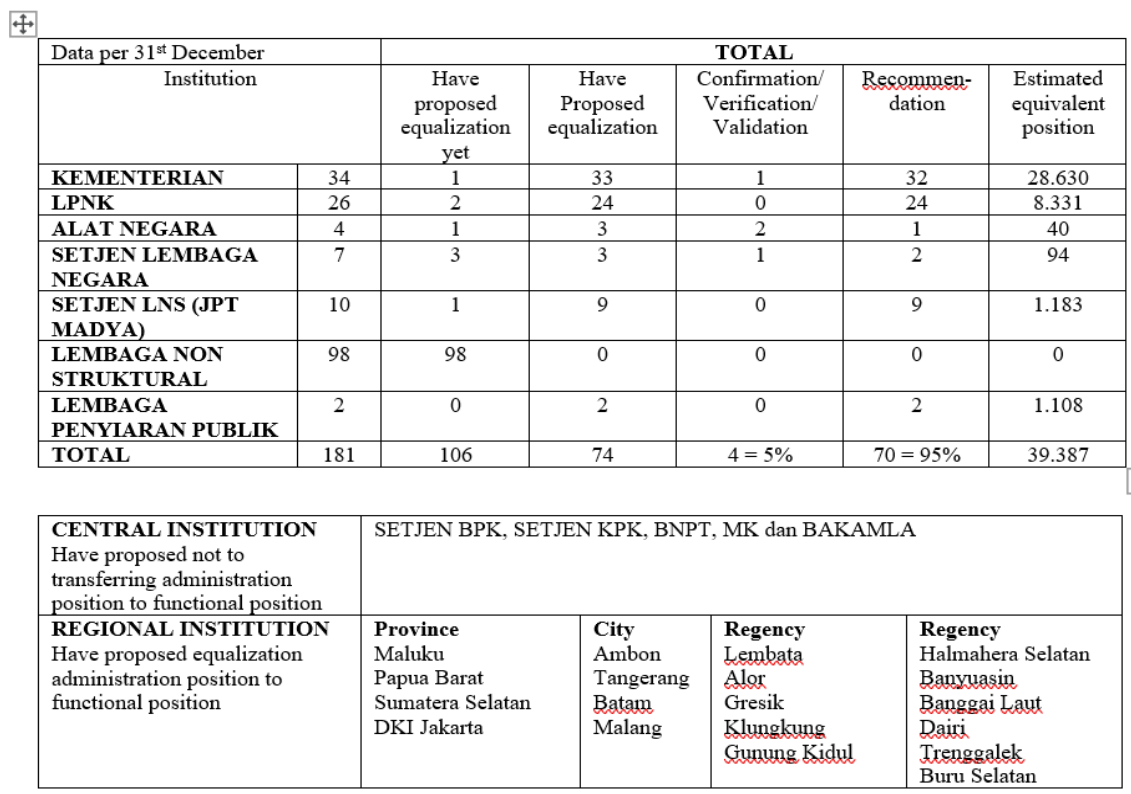

Source : Subagja (2021)

Figure 2. Recapitulation of Agencies Proposing Equalization of Administrative Positions to Professional Positions

Within the scope of regional agencies, the Minister of Home Affairs has sent to Governors and Regents/Mayors throughout Indonesia through the Letter of the Minister of Home Affairs Number 130/4846 / SJ and has been updated with the Letter of the Minister of Home Affairs Number 130/1970 OTDA regarding the follow-up to the bureaucratic simplification process within the local governments. The letter has extended the deadline for the simplification of the bureaucracy within the regional governments. For the identification stage and institutional arrangement of administrative positions that will be transferred to professional positions, namely from March to May 2021. Meanwhile, the stages of approving the results of identification and inauguration of professional positions and reporting of results of bureaucratic simplification to the Ministry of Home Affairs will be carried out no later than June 2021. The minimum number of regional agencies that have proposed since the legal umbrella governing bureaucratic simplification is considered less strong because it is only in the form of a letter so that the implementation experiences limitations. For this policy to be effective, the government should be firm with regional agencies by issuing regulations to accelerate the implementation of bureaucratic simplification in regional agencies. Kemenpan RB can coordinate with the Ministry of Home Affairs in terms of formulating technical policies so that bureaucratic simplification can run effectively.

From Figure 2 above, it can be seen that there are 39,387 positions have currently been equalized. The government must take firm action so that officials affected by the equalization of positions can work and actualize their duties and responsibilities professionally in a new position path. The legal aspect is one of the fundamental aspects because in this case, it provides guarantees regarding the rights and obligations of professional officials who are affected by the equalization of positions. Moreover, the position equalization policy has an impact on changes in organizational structure and work procedures, changes in job formation, changes in the number and types of professional positions, changes in human resource management and changes in the roles of JPT and JF. So that there must be further regulations that serve as a stepping stone to face the resulting impacts. According to Wati (2017:79), government policies are the main capital for empowering professional positions. 
Regulations regarding the impact of equalization of positions should be comprehensive to anticipate clashes of rules that have the potential to create conflicts in their implementation and confusion for professional officials in carrying out their duties. This is important to avoid resistance of professional officials to regulations that were originally intended to guarantee rights and obligations. It is in line with Sudrajat (2013:94) requires implementing the professionalization of positions, it is necessary to harmonize the law so that it is not sectoral, orientation towards understanding between users and implementers to minimize gaps and the implementation of intensive and periodic supervision. Apart from that it also requires political willingness from the authorities to realize good governance. Judging from the analysis of strategic aspects of the development of professional positions as a result of equalization and previous researches related to the impact of the position equalization policy, the regulations that must be followed up include: (1) Accelerating the implementation of bureaucratic simplification by issuing technical guidelines for the implementation of bureaucratic simplification in central and regional agencies; (2) Refining laws and regulations related to professional clusters, credit numbers and promotion of professional officers as a result of the equalization; (3) Strengthening professional positions through clarification of JF position patterns, rotations and transfers, enhancing competencies, work mechanisms, job appraisals and work benefits; (4) Establishing new professional positions that are substantive and administrative; (5) Building a mechanism for fostering professional positions between JF supervisory agencies and internal technical coaches; and (6) Providing budget to support the transfer of structural positions to professional positions.

The government's commitment in strategic planning for the development of professional positions, In Article 70 of Government Regulation Number 11 of 2017 concerning Civil Service Management, several articles have been updated. It is stated that the functions and duties of professional positions are linked to the achievement of the functions and duties of government agencies. In addition, the existence of professional positions is to respond to community needs in line with their respective fields. For example, teachers are tasked with educating students, doctors provide medical assistance to patients, agricultural extension agents provide knowledge and understanding in agriculture and so on. This can, of course, be the basis for leaders of institutions/agencies to develop professional positions. For the development of a professional position to be in accordance with the direction and goals of the organization, it is hoped that the leadership of the institution/agency can make it one of the indicators of success contained in the planning document. So that the government's commitment in planning the development of professional positions gets clear budgeting support.

The other commitments are also further stated in the Regulation of the Minister of Administrative and Bureaucratic Reform Number 42 of 2018 concerning Appointment of Civil Servants in Professional Positions through Adjustments/In-passing. This policy is one of the policies to facilitate the appointment of civil servants as professional officials. However, these civil servant appointments must go through various competency tests and following the formation required by the agency. The formation is the number and rank of civil servants required in an organization so that the organization can carry out its main tasks within a certain period. To find out the required professional position formation, each agency must have a job analysis document and workload analysis. This document serves as a guideline for determining professional positions and the number of professional officers required by agencies to carry out organizational duties and functions. Leaders of government institutions are also continuously encouraged to conduct studies regarding the need for professional positions. 


\section{Operational Technical Aspect}

During the transition to equalization of positions, the assignment of coordination tasks and functions is given to administrative/managerial officials who experience equalization of positions. The assignment and coordination function are given in the form of additional duties as a coordinator or sub-coordinator. Their duties are coordination of planning, implementation and control, monitoring and evaluation as well as reporting to one substance group in each function description grouping. In other words, the duties of Echelon III and Echelon IV are not immediately eliminated but are transferred to the coordinator and subcoordinator of professional positions. This means that these professional positions can be assigned with similar duties and functions as administrative positions, for example managerial duties and functions. So, even though after the simplification of the bureaucracy there will be vacancies in Echelon III and IV, their functions still exist and are replaced by coordinators and sub-coordinators from professional positions.

As it is known, this professional position is independent, the activities carried out are under the activities listed in the credit figures. If it is charged with the responsibility of carrying out the coordinator's duties, of course, there will be a little difficulty in its accountability. The heavy burden of carrying out two functions at once, namely the professional position function and the 'gray' function of the structural position causes the coordinator and sub-coordinator to complain (Anita et al., 2020). There are differences in the scope of work between structural positions and p rofessional positions. Article 1 of the ASN Law states that the scope of administrative positions in the implementation of functions and duties related to public service and administration and development. While the scope of professional positions is the implementation of the functions and duties related to professional services based on expertise and specific skills.

There is a competency gap that occurs due to the equalization of administrative positions to professional positions. The government must have prepared costs and competency development methods for officials affected by the equalization policy. The development of professional position competencies aims to improve a person's ability to provide good service following organizational goals, carry out tasks according to their function (Kuncara, 2014:95). Furthermore, Irfan (2013:54) in his research states the development of employee competencies in professional positions, in addition to adjusting work abilities with new assignments, is also intended as an effort to improve employee performance.

The concluded improvement of the competence, skills, and technology of a professional official should be contextualized or adjusted to the needs of a professional position in each group or a certain type of position (Anita et al., 2020). Article 9 of the Regulation of the Minister of Administrative and Bureaucratic Reform Number 28 of 2019 concerning Equalization of Administrative Positions into Professional Positions states that implementing agencies are required to conduct competency tests for administrator, supervisor and executor officials who will be equalized to professional positions. The competency test is based on the fact that professional positions are based on certain expertise and skills independent that are grouped into JF Skills. The equalization of positions includes: (1) Administrators are equated with professional positions at the intermediate level; (2) Supervisors are equated with the professional departments at the junior level; and (3) The executor (echelon V) is equated with the first level professional department.

Administrative positions that are equivalent to professional positions are in the JF Skills group. JF Expertise is a professional qualification whose duties and functions require mastery of science and technology in their field of expertise. The priority of attention to the development of the competency of professional positions as a result of this equalization is very important because previous studies have stated that competency has an impact on the 
ability to work to achieve work results that will accumulate in the achievement of organizational performance indicators.

To achieve this, government agencies need to develop a quality system for professional positions that are integrated with agencies for developing professional positions (Makmur, 2013). The professional position quality system can be interpreted as a whole series of interconnected, related, influential processes in realizing an increase in the competency of a professional position. Structuring aspects needed in developing a quality system for professional positions include:

a. Availability of information tools

b. Competency standards

c. Assessment of the competence of professional officials

d. Competency development

e. Provision of learning organizations

f. Job appraisal model, target setting and performance contract

g. Performance evaluation.

Mutual commitment from all parties is required to realize sustainable implementation of competency development. For this reason, a leadership role is needed to develop an effective work culture that is able to encourage professional officials to understand their duties (Yohanitas, 2020:31). Apart from commitment, other factors are also needed such as a developed work culture such as knowledge sharing. Sharing knowledge is the process of exchanging knowledge or information that can improve the competency of a professional official, for example through mentoring from leaders or more senior professional officials. This work culture also requires the self-awareness of each individual so it takes motivation from each professional official.

\section{Welfare Aspect}

This bureaucratic simplification also has implications for the aspects of employee welfare, employees who previously had structural allowances have to switch to professional positions. The transition of structural positions is not an easy thing to do, because so far structural positions have been regarded as lucrative positions with all the fringe benefits, so it is only natural that potential resistance arises against this simplification of the bureaucracy. Employee welfare has a significant effect on employee performance (Nizamuddin, 2020: 158). One of the components of employee welfare is salary. Salary consists of elements of basic salary, periodic salary increases, special salary increases and allowances. So far, the government has established a civil service payroll system with a combined scale system that determines civil servant salaries based on rank so that civil servants who excel are still given the same basic salary. Irfan $(2013: 49)$ says that providing compensation based on employee performance is an accurate strategy that can be carried out by an organization to achieve various goals in terms of human resource management. Performance-based compensation has a significant effect so that it motivates employees to work better so that they can achieve organizational goals.

In the context of the equation of administrative positions to professional positions, the authors makes a comparison between the number of benefits for administrative positions that are equated with professional positions that are relevant to the administrative positions that are equated.

Based on the comparison table 4, it can be described that the position allowance received by administrator officers which are equivalent to the professional position of an intermediate expert policy analyst, intermediate expert trainer, intermediate expert staffing analyst is smaller but not too significant than that of the allowance received when serving as an 
administrator. However, when compared to the position of middle budget analyst, the allowances received are higher but not too significant than that of the allowance for administrator positions. On the other hand, the position allowances received by supervisory officials which are equivalent to professional positions of budget analysts, policy analysts, staffing analysts and trainers are quite different and larger than that of the officer allowances received while still in supervisory positions. So that it is more profitable for the supervisor position transferred to a professional position than that of an administrative one.

Table 4. Comparison of the Amount of the Position Allowance

\begin{tabular}{clcccc}
\hline No & Structural & $\begin{array}{c}\text { Policy } \\
\text { Analyst }\end{array}$ & Trainer & $\begin{array}{c}\text { Human } \\
\text { Resource } \\
\text { Analyst }\end{array}$ & $\begin{array}{c}\text { Budget } \\
\text { Analyst }\end{array}$ \\
\hline 1 & Echelon III & Senior & Senior & Senior & Senior \\
& $1,260,000$ & $1,150,000$ & $1,000,000$ & $1,080,000$ & $1,380,000$ \\
2 & Echelon IV & Junior & Junior & Junior & Junior \\
& 540,000 & 920,000 & 700,000 & 840,000 & $1,100,000$ \\
\hline
\end{tabular}

Source: Processed by researchers from various regulations

In addition, employee income also comes from performance allowance. The performance allowance is based on the level of the position. The level of position is measured based on the class of position and the value of the position. The class of office and the value of the position determine the nominal benefits received by each employee. The greater the class of position and position value of an employee, the greater the nominal allowance s/he receives.

Table 5. Comparison of Class of Position and Performance Benefits in National Institute of Public Administration

\begin{tabular}{cccccc}
\hline No & $\begin{array}{c}\text { Class of } \\
\text { Position }\end{array}$ & $\begin{array}{c}\text { Policy } \\
\text { Analyst }\end{array}$ & Trainer & $\begin{array}{c}\text { Human } \\
\text { Resource } \\
\text { Analyst }\end{array}$ & $\begin{array}{c}\text { Budget } \\
\text { Analyst }\end{array}$ \\
\hline 1 & Echelon III & Senior & Senior & Senior & Senior \\
& 12 & 12 & 11 & 11 & 11 \\
& $9,896,000$ & $9,896,000$ & $8,757,600$ & $8,757,600$ & $8,757,600$ \\
2 & Echelon IV & Junior & Junior & Junior & Junior \\
& 9 & 10 & 9 & 9 & 9 \\
& $5,079,200$ & $5,979,200$ & $5,079,200$ & $5,079,200$ & $5,079,200$ \\
\hline
\end{tabular}

Source: Processed by authors from various regulations

Comparing the differences in class positions and performance allowances for administrative positions and professional positions, authors took an example from the National Institute of Public Administration. Based on the table above, the administrator officials who are equivalent to the position of middle policy analyst are still in the 12th grade, but the administrator officials who are equalized to the positions of middle trainers, middle staff analysts and middle budget analysts have decreased the class of positions from 12 to 11 . This is, of course, very detrimental to administrator officials who are equalized to the professional positions mentioned above. On the other hand, for supervisory officials who are equalized to the position of policy analyst, the position class is upgraded from 9 to 10, while supervisory officials who are equalized to the positions of junior trainers, junior staff analysts and junior budget analysts are still in the same class of position, namely 9 . The policy analyst professional position class makes this position most desirable, as seen from the equalization of 808 positions at the Ministry of Home Affairs, around 35 percent or 281 positions are equalized to policy analyst professional positions (Ministry of Home Affairs, 2021).

The policy of bureaucratic simplification through the transfer of administrative positions to professional positions must take into account the capacity and budget obligations of central and regional agencies in ensuring the welfare of professional officials. From the comparative 
analysis of income from administrative positions and professional positions, it is undeniable that there is an income gap. Therefore, the current government must be smart in dealing with budget adequacy to provide welfare for professional officials. If the welfare of professional officials can be fulfilled, the capacity of professional positions in government agencies can be run optimally. In addition, the need for actualization and self-development of professional officials is no longer impossible.

The implications of the development of professional positions when viewed from the three strategic aspects of the analysis above are ideal, every organization should have a job map to meet the needs of the organization. The transfer of administrative positions to professional positions must also look at the availability of job maps. So that the determination of the professional positions to occupy their jobs can encourage the achievement of the organization's vision and mission.

\section{E. CONCLUSION}

This article shows that in developing a professional position that comes from the equalization of positions, three strategic aspects must be considered, namely including legal / law aspects, technical operations, and welfare aspect. Based on these considerations, the development of professional positions in a comprehensive manner can become a staffing management decision based on needs. As a form of scientific contribution to this article, the author compiles several recommendations that are considered worthy to be considered in the development of professional positions.

First, from the legal/law aspect, the policy of equalizing administrative positions to professional positions has not been effective, especially in the scope of regional agencies. In addition, this policy has implications for changes in organizational structure and work procedures, changes in job formation, changes in the number and types of professional positions, changes in human resource management and so on. Therefore, the government must act decisively to find out alternative solutions to overcome these implications.

The regulations that must be immediately followed up include: (1) Accelerating the implementation of bureaucratic simplification by issuing technical guidelines for the implementation of bureaucratic simplification in central and regional agencies; (2) Refining laws and regulations related to professional clusters, credit numbers and promotion of professional officers as a result of the equalization; (3) Strengthening professional positions including clarity on JF position patterns, rotation and transfer, increasing competence, work mechanisms, job appraisals and professional position allowances; (4) Establishing new professional positions that are substantive and administrative; (5) Building a mechanism for fostering professional positions between JF supervisory agencies and internal technical coaches; and (6) Providing budget allocation to support the transfer of structural positions into professional positions.

This aspect also requires the commitment of the central and regional governments through a planning system that accommodates the development of professional positions resulting from the distribution of administrative positions and the development of professional positions in the future considering the very dynamic needs of the community for professional positions.

Second, from the operational technical aspect to support the development of competence for professional positions, the government needs to develop a quality system for professional positions that is integrated with the agency for fostering professional positions. The quality system for professional positions must be able to regulate from upstream to downstream related to the development of professional positions including the provision of information devices that accommodate competency standards, competency development to job appraisals and job evaluations. 
Third, from the welfare aspect, there is an income gap between administrative positions and several professional positions. To work around this, it is necessary to adjust the number of allowances for certain professional positions. This is expected to be able to encourage the work motivation of employees who have moved to professional positions.

Finally, the process of equalizing positions does not drag on. Then the process of transferring positions is not just fulfilling the president's demands without seeing any impact. The income gap between administrative positions and newly occupied professional positions can also be minimized.

\section{REFERENCES}

Andhika, L. R. (2018). Dari Struktur Birokrasi Tradisional Ke Model Adhocracy: Struktur Organisasi Inovatif. Publisia (Jurnal Ilmu Administrasi Publik), 3(1), 11-24.

Anita, Latief, N. K., Milawaty, Sukarno, A., Muskamal, Damayanti, A. S., Zaenal, Z., Arsalam, S., Laksana, S. E. T., \& Iqbal, M. (2020). Kajian Perencanaan Pengembangan Karir PNS (Studi Kasus Penyetaraan Jabatan Struktural-Fungsional Dalam Rangka Penyederhanaan Birokrasi).

Arsalam, S. (2020). Portrait Of Bureaucratic Trimming In The Bureaucratic Reform Era. Jurnal Administrasi Publik, XVI, 155-166.

Aulia Rakhman, F. (2020). Pengalihan Jabatan Struktural Ke Jabatan Fungsional : Suatu Analisa Kompensasi Atas Penghapusan Jabatan Eselon III dan IV Di Pusat Pengembangan Sumber Daya Manuasia Aparatur. JURNAL APARATUR, 4(2). https://doi.org/10.52596/ja.v4i2.12

Badan Kepegawaian Negara. (2020). Buku Statistik Pegawai Negeri Sipil Juni 2020.

Biro Kepegawaian. (2021). Strategi Peningkatan Profesionalisme Dan Kompetensi Bagi Pejabat Fungsional Dalam Mendukung Implementasi Pelayanan Publik di Pusat dan Daerah. Webinar Prospek dan Tantangan Birokrasi Pasca Penyetaraan Jabatan Administrasi menjadi Jabatan Fungsional. Pusat Pengembangan Sumber Daya Manusia. Kementerian Dalam Negeri Regional Yogyakarta.

Burma, Z. A. (2014). Human Resource Management and Its Importance for Today's Organizations. International Journal of Education and Social Science, 1(2), 85-94. https://doi.org/10.29070/15/57308

Dahlia. (2020). Flattening Indonesia's Bureaucratic Structure : A Literature Review On The Urgencies And Consequences. Jurnal Transformasi Administrasi, 10(1), 1-17.

Daniarsyah, D. (2020). Menghalau Perilaku Kontraproduktif: Transformasi Jabatan Administrasi Menjadi Jabatan Fungsional. JIPAGS (Journal of Indonesian Public Administration and Governance Studies),4(1).https://doi.org/10.31506/jip ags.v4i1.7794

Faedlulloh, D., Maarif, S., Meutia, I. F., \& Yulianti, D. (2020). Birokrasi dan Revolusi Industri 4.0 : Mencegah Smart ASN Menjadi Mitos Dalam Agenda Reformasi Birokrasi. Jurnal Borneo Administrator, 16(3), 313-336. /https://doi.org/10.24258/jba.v16i3.736

Faedlulloh, D., Yulianto, Y., \& Karmilasari, V. (2020). A Structural and Mindset Bureaucratic Reform Agenda for Jokowi's Second Term. BISNIS \& BIROKRASI: Jurnal Ilmu Administrasi Dan Organisasi, 27(2), 67-77. doi.org/10.20476/jbb.v27i2.11 466

Fitrianingrum, L., Lusyana, D., \& Lellyana, D. (2020). Pengembangan Karier Jabatan Fungsional Dari Hasil Penyetaraan Jabatan Administrasi: Analisis Implementasi Dan Tantangan Development of Professional Position Career Resulted From Administration Position Equalization:Civil Service, Jurnal Kebijakan Dan Manajemen PNS,14(1),43-54.

Irfan, M. (2013). Pengalihan Jabatan Struktural Ke Jabatan Fungsional: Suatu Telaahan Penghapusan Jabatan Eselon III dan IV Di Badan Kepegawaian Negara. Jurnal Kebijakan Dan Manajemen PNS, 7(1), 40-55.

Kubheka, I., Kholopane, P., \& Mbohwa, C. (2013). The Effects of Flattening Hierarchies on 
Employee Performance in Organizations: A Study of a South African Retail Group. International Conference on Law, Entrepreneurship and Industrial Engineering, 217-222.

Kuncara, W. T. (2014). Manajemen Karir Pada Jabatan Fungsional di Kementerian Kehutanan RI. Publisia:Jurnal Ilmu Administrasi Publik, 18(1), 90-98.

Makmur, M. T. (2013). Pengembangan Sistem Mutu Jabatan Fungsional Pegawai Negeri Sipil Untuk Mendukung Implementasi Reformasi Birokrasi. Jurnal Kebijakan Dan Manajemen PNS, 7(1), 28-39.

Peraturan Menteri Pendayagunaan Aparatur Negara dan Reformasi Birokrasi Nomor 28 Tahun 2019 tentang Penyetaraan Jabatan Administrasi ke dalam Jabatan Fungsional, (2019). Nindyati, A. D. (2017). Pemaknaan Loyalitas Karyawan Pada Generasi X Dan Generasi Y (Studi Pada Karyawan Di Indonesia). Journal of Psychological Science and Profession, 1(3). https://doi.org/10.24198/jpsp.v1i3.15230

Nizamuddin, N. (2020). Efektivitas Penyederhanaan Birokrasi Pemerintah pada Masa New Normal. Jurnal Manajemen Tools, 12(2), 151-159.

Nurhestitunggal, M., \& Muhlisin. (2020). Penyederhanaan Struktur Birokrasi: Sebuah Tinjauan Perspektif Teoritis dan Empiris Pada Kebijakan Penghapusan Eselon III dan IV. Jurnal Kebijakan Pembangunan Daerah, 4(1), 1-20.

Purwanto, A. (2020). Implication of Bureaucratic Reform Policy In Echelon III and IV In The Environmental Services Office of Blora Regency. DiA: Jurnal Administrasi Publik, 18(1), 175-185. https://doi.org/DOI: 10.30996/dia.v18i1.3613

Rohida, L., Nuryanto, Y., \& Syarif. (2018). Implementasi Pengalihan Jabatan Struktural Ke Jabatan Fungsional Melalui Inpassing / Penyesuaian (Studi Kasus Di Universitas Padjadjaran). Civil Service, 12(1), 11-22.

Situmorang, C. H. (2019). Study Analysis UU ASN, Menuju Penyederhanaan Birokrasi (The Act of ASN, Toward Bureaucratic Trimming). Jurnal Populis, 4(8), 1233-1252. https://doi.org/10.47313/ppl.v4i8.699

Subagja, A. (2021). Transformasi Pengembangan Karir Dalam Mendukung Penyederhanaan Birokrasi Pemerintah Daerah. Rapat Koordinasi Percepatan Penerapan Peraturan Menteri PANRB Nomor 17 Tahun 2021 tentang Penyetaraan Jabatan Administrasi ke dalam Jabatan Fungsional se-Jawa dan Bali. Kementerian Pendayagunaan Aparatur Negara dan Reformasi Birokrasi.

Sudrajat, T. (2013). Gagasan Tentang Fungsionalisasi Jabatan Dalam Rangka Reformasi Birokrasi. Jurnal Kebijakan Dan Manajemen PNS, 7(1), 84-95.

Thompson, C. A. (2017). Leading a Multigenerational Workforce in the Public Sector. ProQuest Dissertations and Theses.

Toimsar, N. N. A., Basri, M., \& Manguntara, L. (2018). Reformasi Birokrasi Melalui Penataan Kelembagaan Pada Sekretariat Daerah Kota Kendari. Journal Publicuho, 1(2), 53-63. https://doi.org/10.35817/jpu.v1i2.5828

Wati, R. (2017). Pemberdayaan Pejabat Fungsional Tertentu: Studi Kasus Pada Jabatan Peneliti dan Perencana Di Bappeda Provinsi Bengkulu. Civil Service, 11(2), 67-80.

Yohanitas, W. A. (2020). Eksistensi Unit Kerja Dalam Pengembangan Kompetensi Pejabat Analis Kebijakan di Lembaga Administrasi Negara. Jurnal Ilmu Administrasi: Media Pengembangan Ilmu Dan Praktek Administrasi, 17(1), 16-34.

Zulyani, E. P., \& Meiwanda, G. (2020). Agile Government Dalam Mewujudkan Birokrasi Yang Berkelas Dunia. Spirit Publik, 15(1), 78-86. 